\title{
The System of Lithuanian Protected Territories from Environment Conservation Point of View
}

\author{
Jolanta Margelienè, Aušra Budrienė \\ Kaunas University of Applied Sciences, Faculty of Landscaping \\ Department of Green Plantations and Agro technologies \\ Mokslo st. 2, Mastaičiai, 53313 Kaunas reg.; \\ e-mail: j.margeliene@kauko.lt,ausra.budriene@gmail.com
}

\begin{abstract}
The article analyses the system of Lithuanian protected territories as well as their types form environment conservation point of view. The system of protected territories of LR includes the following types of areas: 6 state reserves, 1 biosphere reserve, 396 strict reserves, 5 national parks, 30 regional parks, 29 biosphere polygons and 3 recuperation plots. The system of protected territories, the order of establishment, management and the legal basics of protection of protected territories is determined by the law of protected areas of LR that was approved in 1993. The purpose of reserves is to preserve unique landscape complexes, their biota gene pool, to organize scientific research and observation, to promote natural and cultural values. The aims of the establishment of Lithuanian national and regional parks are not only to preserve naturally and culturally valuable landscape but also to support ethno cultural traditions of Lithuanian regions and to provide conditions for recreation. The purpose of strict reserves is to preserve the complexes of natural and cultural heritage or separate landscape elements, plant and animal species, to secure landscape diversity and ecological balance. Live and inanimate natural monuments are preserved naturally for scientific, cultural, educational and aesthetic needs. The purpose of biosphere polygons is to preserve bird species by assuring favorable conditions, to perform the monitoring of protected species, scientific research, etc. The aim of the recuperation plots is to restore natural resources. The system of Lithuanian legal acts allows applying such limitations that are necessary to preserve existing values in every protected territory.
\end{abstract}

Keywords: protected natural territories, reserves, strict reserves, national and regional parks, natural monuments, biosphere polygons, recuperation plots.

\section{INTRODUCTION}

Due to the development of industry, transport, agriculture and other economic activities as well as the impact of urbanization country landscape is also undergoing significant changes; therefore, different protected territories have been established.

Environmental conservation traditions in Lithuania are very old. Sacred forests situated near the river Nevėžis were mentioned in Salyno pact in 1398. Since 1420 cuttings of old oaks were prohibited in Lithuania. The Wallach reform of 1557 identified the order of forest fellings, hunting, mushroom and berry picking. During the Soviet period (in 1959) the environment protection law of Lithuania SSR was passed. After the restoration of independence the law of protected territories of the Lithuanian Republic was passed in 1993 [2].

Exceptional character of protected territories as the object of used and protection is shown by the peculiarities of its protection regime that are determined by the specifics of their aim and functions. [3]. The aim of protected territories is complex: the territories are established in order to preserve not only natural, but also cultural-historical landscape and its objects. They should provide conditions for the organization of recreational, scientific research, environment observation activities.

Every country creates its unique system of protected territories. In this process Lithuania has chosen an integrated approach, i.e. integrated protection of natural and cultural heritage when both animate and inanimate natural values are preserved.

Big changes in the system of protected territories take place because of the obligations of Lithuania to the European Union to establish the network of protected territories „Natura 2000“by the year 2015.

The system of protected territories is not stagnant; the network is constantly reviewed and supplemented.

Aim: To analyze the structure, types and functions of the system of Lithuanian protected territories from the environment conservation point of view.

\section{MATERIALS AND METHODS}

Work methods:

1. Analysis of scientific references.

2. Statistic data analysis.

3. Analysis of the use and legal protection regulation of protected territories. 
Work object: The types of the Lithuanian protected areas: reserves, national and regional parks, strict reserves, biosphere polygons, recuperation plots.

\section{RESULTS}

Protected territories are dry land and (or) water areas that have approved scientific, ecological, cultural and other value and where special protection and use regime has been established [1].

In Lithuania the system of protected territories has been started to be created in 1937 when following the initiative of T. Ivanauskas the Žuvintas reserve was established. Since 1960 quite a big number of strict reserves have been established. In 1974 the first Lithuanian national park has been founded. After the restoration of Lithuanian independence (in 1992) a lot of protected areas, especially regional parks have been established. Preservation of values is not possible without legal foundation that is why the legal base for protected territory system, its establishment, management and protection is defined by the law of protected areas of LR approved in Lithuania in 1993. The system of protected territories of LR includes the following types:
6 state reserves,

1 biosphere reserve,

396 strict reserves,

5 national parks,

30 regional parks,

29 biosphere polygons,

3 recuperation plots.

Lithuanian protected territories take up about $14 \%$ of the country territory area [5]. The distribution of the types of protected territories according to the area is the following: regional parks $-44 \%$., biosphere polygon -23 $\%$, strict reserves- $15 \%$, national parks - $14 \%$, reserves $-2 \%$ and recuperation plots $-0,1 \%[1]$.

Reserves are protected areas established for the protection of extremely valuable natural or cultural territorial complexes as well as for scientific research, maintenance of natural flow of nature processes or the authenticity of cultural values, and the propagation of the protection of territorial complexes of natural and cultural heritage [5].

Reserves are divided into natural (for the preservation of extremely valuable natural landscape complexes) and cultural (for the preservation of extremely valuable cultural landscape complexes).

The characteristics of reserves are presented in Table 1.

TABLE 1

CHARACTERISTICS OF LITHUANIAN RESERVES (MARGELIENĖ, 2013)

\begin{tabular}{|l|l|l|l|l|}
\hline Reserve & Category & $\begin{array}{l}\text { Year of } \\
\text { establishment }\end{array}$ & $\begin{array}{l}\text { Area, } \\
\text { ha }\end{array}$ & Environmental characteristics \\
\hline Čepkeliai & Natural & 1975 & 11212 & $\begin{array}{l}\text { It is the moor and forest complex of peculiar natural value which has not } \\
\text { been damaged by human activity. The peat-moss swamps contain dwarf } \\
\text { pines; Eurasian curlews, European Golden Plovers and wood sandpipers } \\
\text { brood in open areas, cranberries grow their berries. Upland moor contains } \\
\text { over 20 small lakes. In the Southern part the moor changes into the } \\
\text { lowland moor, sedge wet meadows that give the origin to Musteika rivulet } \\
\text { Katra rivulet flows along the Southern boundary of the reserve. There are } \\
\text { alot of rare species of plants, white-tailed eagles, ospreys, black storks, } \\
\text { little eagles, Western capercaillies as well as black grouse brood here. It } \\
\text { contains the largest population of cranes (up to 25 pairs), moose, wolves, } \\
\text { and lynxes. }\end{array}$ \\
\hline Kamanai & Natural & 1979 & $\begin{array}{l}\text { The biggest part of the reserve is occupied by a moor with numerous } \\
\text { swamps and lakelets (up to 120). Several decades ago the moor was } \\
\text { drained. This had a significant impact on it and the plants growing there. } \\
\text { At the moment the reserve water regime has been restored, nature } \\
\text { processes are naturalizing. The most impressive lakelets are Nimfëjai and } \\
\text { Salu as well as Kamanu lake, the area of which is 6 ha. The moor is } \\
\text { surrounded by mixed forests and shady spruce forests. A lot of rare species } \\
\text { of plants are found in the reserve. Cypripedium calceolus are abundant } \\
\text { here. European Golden Plovers, black storks, black grouse brood here. } \\
\text { Wolves and lynxes live here. }\end{array}$ \\
\hline Viešvile & Natural & 1991 & $\begin{array}{l}\text { Reserve is composed of Artosios and Gličio moors with Buveiniu and } \\
\text { Gličio lakes, Viešvilès rivulet and impressive part of Karšuva forest. Only } \\
\text { about15 km long Viešvilès rivulet outflows from boggy Buveiniu lakelet } \\
\text { and flows into the river Nemunas. The rivulet flows through moors, } \\
\text { meadows and shadowy mixed forests. It is the home for trouts and otters. } \\
\text { Away from the rivulet and the moor there are nice pine forests. European } \\
\text { Golden Plovers, cranes brood in the reserve moors, little eagles, stock } \\
\text { doves brood in the forests. There are wolves, moose, and lynxes. }\end{array}$ \\
\hline
\end{tabular}




\begin{tabular}{|c|c|c|c|c|}
\hline Kernavė & Cultural & 1989 & 199 & $\begin{array}{l}\text { Lithuania has the only archeological and historical museum-reserve in } \\
\text { Kernave. It was established in } 1989 \text { in Šrvintai dist. Its area is 196,2 ha. } \\
\text { Reserve was established close to the river Neris, in Pajauta valley. It has a } \\
\text { complex of } 5 \text { mounds as well as the places that have a lot of archeological } \\
\text { findings that are important for Lithuanian history. Kernave was mentioned } \\
\text { in written sources in } 1279 \text {. Following archeological findings it was } \\
\text { identified that the first inhabitants settled down in this place in IX-VIII } \\
\text { centuries BC. In XII century Kernave became the town, the centre of } \\
\text { which was } 4 \text { mounds.. Altar mound contained duke estate, the others - } \\
\text { protective castles. In the base of mounds the town was created with the } \\
\text { quarters of craftsmen and merchants. After the Teutonic Order attacks in } \\
1390 \text { the town was abandoned; it was buried and preserved for future } \\
\text { research by the silt of the river Neris. }\end{array}$ \\
\hline Vilnius castles & Cultural & 2002 & 360 & $\begin{array}{l}\text { State cultural reserve of Vilnius castles is the heart of Vilnius old town. } \\
\text { Archeological values: Vilnius mound (A1961 K) - which is called } \\
\text { Kreivuoju (Crooked) mound, Plikuoju (Naked) mound, the mound of } \\
\text { Three Crosses (A1961 K1) together with low castles is also called Bekešo } \\
\text { mound (A1961 K2), Gediminas grave mound (A1961 K3) and Stalo } \\
\text { (Table) mound (A1961 K4). The area of the territory is 33,87 ha. Vilnius } \\
\text { castle land (A1960) is called Gediminas castle mound, Upper castle, } \\
\text { Lower castle. The area of the territory is 18,70 ha. Architectural values: } \\
\text { the complex of Arch cathedral basilica, Lower and Upper castle and their } \\
\text { remnants (G205 K). Building complex (G390 K): Palace, called Kirdieju } \\
\text { (G390 K1), Barboros Radvilaitė, Office (G390 K2), cart shed (G390 K3), } \\
\text { fence (G390 K4). Other values: The monument of Three Crosses (D } \\
\text { R1332), sculptural composition, „Lithuanian ballad" (D V3557). }\end{array}$ \\
\hline Dubrava & Reserve area & 1994 & 120 & $\begin{array}{l}\text { The purpose is to preserve rare forest plantings, productive coniferous } \\
\text { plantations and valuable plant communities. Very valuable natural high } \\
\text { moor. }\end{array}$ \\
\hline Žuvintas & Biosphere & 2002 & 18493 & $\begin{array}{l}\text { Žuvintas biosphere reserve territory contains a lot of valuable biotypes. } \\
\text { Active high moors, intermediate moors, low moors, high moor pine } \\
\text { stands, wet black alder stands as well as eutrophic Žuvintas lake can be } \\
\text { found in Žuvintas natural reserve. Žuvintas is the most famous because of } \\
\text { birds. Since } 1980227 \text { bird species were observed in Žuvintas biosphere } \\
\text { reserve. } 153 \text { species have brooded here. } 108 \text { of mosses, } 105 \text { algae, } 107 \\
\text { fungi and more than } 600 \text { species of higher plants are found here. About } \\
2000 \text { species of insects, } 5 \text { reptiles and } 10 \text { recorded, over } 40 \text { species of } \\
\text { mammals were found. } 22 \text { species of fish are found in Žuvintas lake. }\end{array}$ \\
\hline
\end{tabular}

National parks are the territories protected by Lithuanian state with specific landscape, unique settlements, and cultural values [5]. Sightseeing tourism is promoted in national parks and the attempt to introduce visitors to natural and cultural values has been made. Human activity limited in these areas, it carefully combined with environmental conservation. Lithuania has five national parks: Aukštaitija, Žemaitija, Trakai historical, Dzūkija and Kuršių Nerija (fig 1.).

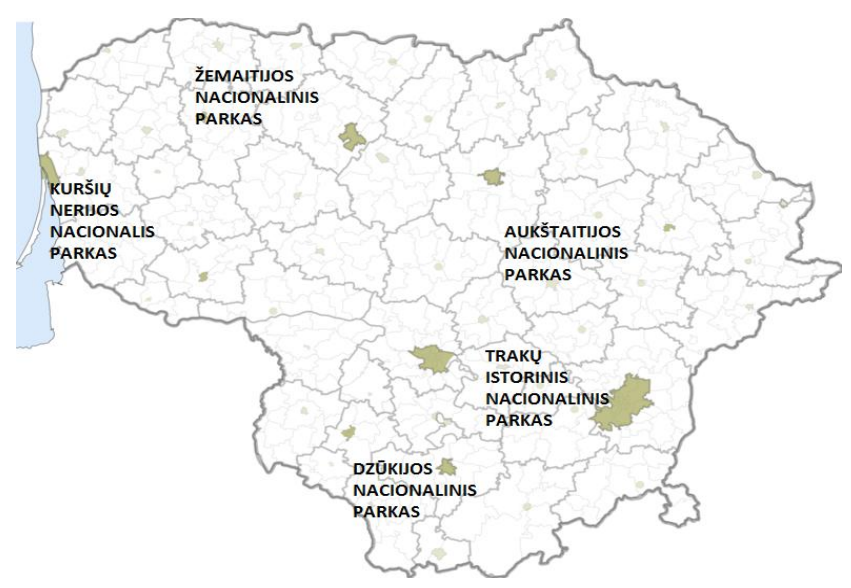

Fig. 1. Lithuanian national parks (www.lvmi.lt)

Characteristics of the Lithuanian national parks are presented in Table 2 . 
TABLE 2.

CHARACTERISTICS OF LITHUANIAN NATIONAL PARKS (MARGELIENĖ, 2013)

\begin{tabular}{|c|c|c|c|}
\hline National park & $\begin{array}{l}\text { Year of } \\
\text { establishment }\end{array}$ & $\begin{array}{l}\text { Area, } \\
\text { ha }\end{array}$ & Conservation characteristics \\
\hline Aukštaitija & 1974 & 40570 & $\begin{array}{l}120 \text { lakes and } 70 \text { rivers are scattered among the woods and hills. Šilininku ridge is situated here. } 50 \\
\% \text { of the territory is occupied by forests. Moors are concentrated in the hollows. } 900 \text { species of plants } \\
\text { grow there; } 60 \text { of them are included into Lithuanian Red List (Cypripedium calceolus, Liparis } \\
\text { loeselii, Saxifraga hirculus, etc.). About } 200 \text { bird species have been found in the park. Ažvinčiu old } \\
\text { forest and Minčios forest are of a special value. }\end{array}$ \\
\hline Dzūkija & 1991 & 55920 & $\begin{array}{l}\text { This is the biggest and the most forested national park in Lithuania. Two thirds of the territory is } \\
\text { located in the sandy plain of the southeast of Lithuania. There are lots of rivers - Merkys, Üla, Grūda } \\
\text { etc. } 50 \text { lakes. Surroundings of Merkine are especially spectacular. Almost all territory of the park is } \\
\text { overgrown by forests. Lichen Scots pine and whortleberry pine forests dominate. } 750 \text { species of } \\
\text { higher plants, } 300 \text { species of fungi, } 40 \text { species of mammals and } 150 \text { species of birds are found here. }\end{array}$ \\
\hline Kuršių nerija & 1991 & 26464 & $\begin{array}{l}\text { The aim is to preserve the grand ridge of Kuršių Nerija, old dunes near Juodkrante, grey dunes in } \\
\text { Agila-Naglis strip. The peak of the majority dunes is } 60 \mathrm{~m} \text {. This landscape is the youngest in } \\
\text { Lithuania. The dry land occupies } 50 \% \text { of park territory, the remaining part is the Baltic sea and } \\
\text { Curonian Lagoon. About } 70 \% \text { of dry land is occupied by forests dominated by pines. } 1000 \text { species of } \\
\text { rare and interesting plants such as Eryngium maritimum, Erica tetralix, Gypsophila paniculata, etc. } \\
\text { grow there. There is a huge variety of birds. }\end{array}$ \\
\hline $\begin{array}{l}\text { Trakai } \\
\text { historical }\end{array}$ & 1991 & 8200 & $\begin{array}{l}\text { This is the smallest national park. Almost half of the territory is overgrown by forests and } 16 \% \text { of the } \\
\text { park is occupied by water. Park territory is connected by the system of } 30 \text { lakes - Galvès, Skaisčio, } \\
\text { Bernardinu etc. Coregonus albula live in the lakes. The castles of Trakai Island and Peninsula are } \\
\text { situated there. There are a lot of black storks, Montagu's Harriers, Corncrakes and other species of } \\
\text { birds. The highest place of the park is Nuobariškiai hill. }\end{array}$ \\
\hline Žemaitija & 1991 & 21720 & $\begin{array}{l}\text { Plateliai lakes and their surrounding natural complex is a very important part of the park. Forests } \\
\text { occupy almost half of the park territory, spruce forests dominate. } 26 \text { lakes are located in the park. The } \\
\text { biggest of them is Plateliai lake ( } 1200 \text { ha). The biggest river is Babrungas. } 60 \text { plant species included } \\
\text { into Lithuanian Red List grow there. } 180 \text { species of birds, } 50 \text { species of mammals are discovered } \\
\text { there. Rare insects such as clouded apollos, the Old World Swallowtails, the Large Coppers are found } \\
\text { there. Different species of bats are found in the old park trees. }\end{array}$ \\
\hline
\end{tabular}

The purpose of establishing Lithuanian national and regional parks is not only to preserve naturally and culturally valuable andscape, but also to support Lithuanian regional ethno cultural traditions, to provide conditions for recreation [1].

Regional parks are protected territories that have been established to protect the landscape important from natural, cultural and recreational point of view as well as to regulate their recreational and economic use. Lithuania has 30 regional parks (one of them is historical), the area of which is 439842 ha. Regional parks were established in 1992. They are divided into four groups: sea and large water reservoirs (Kaunas reservoir), river valleys of different sizes (Dubysa, Venta, Nemunas loops, etc.), forested lakes and hills (Labanoras, Verkiai, Sartai et..) as well as plateaus and plains (Biržai, Tytuvėnai, Žagarè) [6].

TABLE 3.

CHARACTERISTICS OF LITHUANIAN REGIONAL PARKS (MARGELIENĖ, 2013)

\begin{tabular}{|l|l|l|}
\hline Regional park & $\begin{array}{l}\text { Area, } \\
\text { ha }\end{array}$ & The most important park values \\
\hline Anykščiai & 16269 & The park is famous for: The forest of Anykščiai, Puntukas stone, „Queen's swamp“, etc. \\
\hline Asveja & 11589 & Park focus - Asveja lake which is the longest in Lithuania \\
\hline Aukštadvaris & 15350 & $\begin{array}{l}\text { The standard of Lithuanian flora - Mergiškiai forest, where linden trees grow together with oak, maple and a } \\
\text { mixture of hornbeam trees. }\end{array}$ \\
\hline Biržai & 14659 & Unique landscape of Lithuanian sinkhole region. \\
\hline $\begin{array}{l}\text { Dieveniškiai } \\
\text { historical }\end{array}$ & 8747 & Culturally valuable relics of old Baltic, Dzūkija and Aukštaitija ethno culture. \\
\hline Dubysa & 10571 & Dubysa - one of the biggest and the most beautiful Lithuanian rivers. \\
\hline Gražute & 29700 & The landscape of Šventoji source full of lakes (70 lakes), rivers. \\
\hline Kaunas reservoir & 10221 & This artificial water pond created by humans with impressive bank uncovering of 20-40 m. \\
\hline Krekenava & 11968 & Protected river valleys of Nevěžis, Upytė, Liaude, Vešèta and Linkava. \\
\hline Kurtuvėnai & 15090 & $\begin{array}{l}90 \% \text { of the park is occupied by forests. About 100 Svilè sources of different size well up in Venta-Dubysa old } \\
\text { valley. }\end{array}$ \\
\hline Labanoras & 55344 & It is the biggest Lithuanian regional park in Lithuania. There are 260 lakes, Kanis, Snieginis and other moors. \\
\hline Meteliai & 17729 & Hornbeams are preserved in Giraite forest. There are big lakes: Dusia, Metelys and Obelija. \\
\hline
\end{tabular}




\begin{tabular}{|c|c|c|}
\hline Nemunas delta & 28870 & $\begin{array}{l}\text { It is a low flat plain, made from alluvial silt and lined by rivers and rivulets. It has Ventè cape, Kniaupas bay, } \\
\text { Galzdonai islands, etc. }\end{array}$ \\
\hline Nemunas loops & 25171 & $\begin{array}{l}\text { Meandrous Nemunas valley with high, steep slopes, lined by rivulet valleys and washes. The biggest loops: } \\
\text { Punia, Balbieriškis, Prienai and Birštonas. }\end{array}$ \\
\hline Neris & 10588 & The landscape complex of the Northern edge of Dzūkija highland. \\
\hline Pagramantis & 14420 & The landscape of the confluence valley of Akmena and Jūra rivers and forests \\
\hline Seaside & 5070 & Unique formation - Dutch cap (ridge). \\
\hline Panemuniai & 11563 & The towns of the park are famous because they are valuable from natural and cultural points of view. \\
\hline Pavilniai & 2153 & $\begin{array}{l}\text { The value of the landscape is determined by the relief marked by the differences up to } 100 \mathrm{~m} \text {. Ribiškis wash } \\
\text { (hills) is especially unique. }\end{array}$ \\
\hline Rambynas & 4786 & It is the smallest regional park in Lithuania. Its values: the landscape of Nemunas bends and Rambynas mound. \\
\hline Salantai & 13630 & Natural heart of the park includes the valleys of Minija, Salantas, Bartuva and other rivers. \\
\hline Sartai & 12547 & Sartai lake is the eighth lake in size in Lithuania; it has 7 islands. The line of the lake coast is $80 \mathrm{~km}$. \\
\hline Sirvèna & 8735 & Forests occupy $40 \%$ of the territory. Mixed forests dominate. There are 30 lakes. \\
\hline Tytuvėnai & 10152 & $\begin{array}{l}\text { Unique heritage of the glacial period is Rūža or Velniakelis (Devil's Road), where a stone belt is extended for } \\
\text { several kilometers. }\end{array}$ \\
\hline Varniai & 33800 & $\begin{array}{l}\text { The park contains a lot of mounds such as Medvėgalis, Šatrija, Sprūdè and others. The biggest lake is Lūkstas - } \\
\text { over } 1000 \text { ha. }\end{array}$ \\
\hline Veisèjai & 12200 & There are a lot of narrow and long lakes reminding about rivers. \\
\hline Venta & 10630 & $\begin{array}{l}\text { There are a lot of rivers, no lakes. The river Venta is abundant of fluvial fish - spined loach and European } \\
\text { bitterling }\end{array}$ \\
\hline Verkiai & 2673 & $\begin{array}{l}\text { The adornment of the park is five green lakes situated among the hills overgrown by pine and spruce forests. } \\
\text { Their underground waters are very carbonated. }\end{array}$ \\
\hline Vištytis & 10833 & Vištytis lake. Mature broadleaf forests, oak forests with hornbeam and linden are especially valuable. \\
\hline Žagarè & 4784 & The most valuable is the structure of Žagare town. \\
\hline
\end{tabular}

Strict reserves are protected territories that have been established to protect scientifically and cognitively valuable natural and cultural places as well as their complexes and objects, for the preservation of landscape biological and genetic diversity unimposing economic activity [5]. The purpose of strict reserves is to preserve the complexes of natural and cultural heritage or separate landscape elements, species of plants and animals, to ascertain landscape diversity as well as ecological balance. In Lithuania the network of strict reserves has been started to form in 1960, and the last strict reserves were finished to be established in 1997. At the moment there are 396 strict reserves in Lithuania. Depending on protected values strict reserves can be of different kinds (table 4).

TABLE 4.

CHARACTERISTICS OF STRICT RESERVES (MARGELIENÉ, 2013)

\begin{tabular}{|c|c|c|}
\hline Types of strict reserves & Number & Protected values \\
\hline \multicolumn{3}{|l|}{ State strict reserves - 285} \\
\hline Landscape & 48 & Landscape heritage objects of a special value \\
\hline Geological & 10 & Deep earth structures, exposures, boulders and sinkholes \\
\hline Geomorphologic & 40 & Variety of relief forms \\
\hline Hydrographic & 34 & Structure of rivers, rivulets and lakes \\
\hline Pedologic & 11 & Soil structure \\
\hline Botanical & 35 & Types and communities of plants, fungi, biotopes \\
\hline Botanical-zoological & 29 & Plant types and communities as well as types of animals \\
\hline \multicolumn{3}{|l|}{ Zoological: } \\
\hline teriologicalal & 1 & Bats \\
\hline ornithological & 10 & Birds and their breeding - grounds \\
\hline herpetological & 3 & European pond turtles \\
\hline ichtiological & 9 & Fish and their resources \\
\hline entomological & 6 & Extinct insects and their habitats \\
\hline telmological & 51 & Moors \\
\hline talasological & 1 & Valuable sea ecosystems \\
\hline
\end{tabular}


Biosphere polygons have been established for the observation of national and regional environment in the territories of special geo ecological importance.

They have been established in Lithuania since 2004 to 2006. There are 26 biosphere polygons; their total area is 188777 ha. According to their nature they can be complex or specialized (hydrologic, zoological, etc.). Their purpose is to preserve extinct bird species by assuring favourable conditions, to carry out the monitoring of protected species as well as scientific research, etc. [3]. The most valuable state protected objects of natural heritage are declared as natural monuments.

TABLE 5 .

CHARACTERISTICS OF NATURAL MONUMENTS (MARGELIENĖ, 2013)

\begin{tabular}{|l|l|}
\hline Types of natural monuments & Number \\
\hline Stones & 47 \\
\hline Exposures & 22 \\
\hline Sinkholes & 3 \\
\hline Botanical objects (oak woods, linden, ash woods, etc) & 28 \\
\hline Geomorphologic objects (hills, dunes, etc.) & 29 \\
\hline Hydrographic objects (lakes, peninsulas, islands, etc.) & 13 \\
\hline Hydro geological objects (springs, sources) & 19 \\
\hline
\end{tabular}

Recuperation plots are protected areas for the protection, profusion and limited use of natural resources and their complexes emasculated by human activity. Their purpose is to restore natural resources; they are given the „Natura 2000“territory status which is the network of protected territories of European importance consisting of two directives (Habitations and Birds). Rich Lithuanian biological diversity is very important for ecological EU network „Natura 2000“(Western taiga habitation in Prienai forest, etc.) [6]. Regarding the peculiarities of natural resources protected natural plots of phyto resources (trees, berries, mushrooms, herbs), zoo resources (animal biotopes) and complex resources (recuperation moors as well as underground water ponds) have been established [3].

Some protected territories of Lithuania are important on international level. Čepkeliai, Kamanai and Viešvile natural reserves as well as Žuvintas bio sphere reserve and the regional park of Nemunas delta were included into Convention on Wetlands, Ramsar, and the list of the wetland of international importance in 1993. Kuršiu nerija, Trakai historical national park and Vilnius castle as well as Kernave cultural reserve are included into the list of World heritage (UNESCO). Kuršių nerija national park, regional parks of Nemunas delta and the Seaside were included into the system of the Baltic Sea Protected Areas [2].

The system of Lithuanian legal acts allows applying such limitations that are necessary to preserve existing values in every protected territory (Table 6).

The activity of protected areas is coordinated by the state service of protected territories at the Ministry of Environment.

TABLE 6.

PROTECTION REGIME OF THE PROTECTED AREAS (MARGELIENĖ, 2013)

\begin{tabular}{|l|l|}
\hline Protected territory type & Forbidden activity \\
\hline Reserves & $\begin{array}{l}\text { The change or damage to relief forms; the search and mining of minerals; construction of buildings, } \\
\text { not related to the reserve activity; construction of roads, mains; use of chemicals or other types of } \\
\text { environmental pollutants; change in hydrological regime; fishing and hunting; plant and animal } \\
\text { introductions; any other activity that is considered harmful for the protected ecosystem. }\end{array}$ \\
\hline Strict reserves & $\begin{array}{l}\text { Commercial - economical, construction, recreational and other activity that is harmful to the } \\
\text { environment; construction of industrial objects as well as stationary recreational institutions; } \\
\text { exploitation of minerals; giving land to gardening communities, construction of individual } \\
\text { summerhouses; land drainage; building or deepening of riverbeds; soil destruction; forestation of } \\
\text { glades, natural meadows and pastures; hunting of protected species of animals, introduction of new } \\
\text { animal species; use of pesticides. }\end{array}$ \\
\hline Natural objects & $\begin{array}{l}\text { Any activity that can damage natural values: to damage or to change relief; construction of } \\
\text { mechanisms that are not related to the heritage exploitation or management, etc. }\end{array}$ \\
\hline National and regional parks & $\begin{array}{l}\text { Installation of new mining mineral quarries; expansion or construction of industrial as well as waste } \\
\text { management enterprises; building new communications; construction of big bird, game and animal } \\
\text { farms; establishment of new enterprises; damage or changes in relief; changes in hydrological and } \\
\text { hydrographic regime; giving land to gardening communities, construction of individual } \\
\text { summerhouses; damage to natural and cultural monuments, etc. }\end{array}$ \\
\hline Biosphere polygons & $\begin{array}{l}\text { Certain protection regime is introduced into protective zones. For example, in the protective zone of } \\
\text { a sinkhole region it is forbidden to use the sinkholes for rain and water drainage, to dump rubbish } \\
\text { and waste, to cover them with soil, to mine peat, etc. }\end{array}$ \\
\hline Recuperation plots & Mineral mining and exploitation, the use of land, forests and water are restricted. \\
\hline
\end{tabular}

\section{CONCLUSIONS}

The investigation of scientific and legal documents as well as data revealed that different types of protected areas have been established in Lithuania. They include: 6 state reserves, 1 biosphere reserve, 396 strict reserves, 5 national parks, 30 regional parks, 29 biosphere polygons and 3 recuperation plots. The protected territories occupy about $14 \%$ of the total country territory area. While analyzing the types of protected areas their environmental 
characteristics that represent unique landscaping and biological diversity values that are clearly different from those of unprotected territories were presented. The investigation revealed that the sufficient number of territories has been established. The size of the territories is also adequate which is ensures their preservation. The territories are located evenly what allows for their expansion for visiting. After the identification of the forbidden activities of protected areas protection regime it is possible to say that some problems may be encountered when ensuring the identified protection and use regime. The problems include the undergoing land reform, the regulation of private interests' conflict as well as the lack of legal acts. The protected territories are gradually becoming the part of environmental conservation.

\section{REFERENCES}

[1] Baltrėnas P. ir kt. Aplinkos apsauga. Vilnius, 2008, 564 p.

[2] Kirstukas M. Lietuvos gamta. Saugomos teritorijos. Kaunas, 2004, 391p.

[3] Marcijonas A., Sudavičius B. Ekologinè teisè. Vilnius, 1996, 272 p.

[4] LR Saugomų teritorijų įstatymas. Vilnius, 1993.

[5] Paulauskas A. ir kt. Ekologijos terminų aiškinamasis žodynas. Vilnius, 2008, $503 \mathrm{p}$

[6] Volodka H., Balčiauskas L. Lietuvos gamtinè aplinka. Šiauliai, 2001,158 p. 